\title{
PENGABDIAN PUBLIKASI KARYA LIMIAH (ARTIKEL DAN PROSIDING) GUGUS V SDN KECAMATAN KARANGPLOSO
}

\author{
Farida Nur Kumala dan Dwi Agus Setiawan \\ 1Program Studi PGSD, Universitas Kanjuruhan Malang \\ 2Program Studi PGSD, Universitas Kanjuruhan Malang
}

\begin{abstract}
Abstrak
The purpose of this devotional is to conduct training on scientific publication for elementary school teachers of cluster V Karangploso. The benefit of this dedication is to improve the ability of partners in creating an article that can be published results from PTK activities through scientific journals and proceeding. The method of the implementation of this devotion consists of field visits, socialization, training of articles for scientific journals, article-writing training and scientific proceeding power point as well as tips and tricks in selecting scientific journals and proceedings that ended the mentoring and consultation activities. The results of the implementation program is known response from the teacher who has made scientific writing quite well and has produced five articles of service in the form of articles for scientific journals and articles for national and international proceeding. The next plan is to assist in enrolling in national scientific journals as well as international and national seminars.
\end{abstract}

\author{
Keywords: \\ Karangploso, training of \\ journals articles in \\ elementary education, \\ training articles on $S D$ \\ prosiding
}

\section{Pendahuluan}

Publikasi ilmiah menurut permen no.35/2010 diartikan karya tulis yang telah dipublikasikan kepada masyarakat. Publikasi ilmiah terdiri dari hasil penelitian atau gagasan inovatif pada bidang pendidikan formal dana publikasi teks pelajaran, buku pengayaan dan pedoman guru. Publikasi dapat diartikan sebagai kegiatan penyebarluasan informasi kepada masyaraka berdasarkan hasil dari penelitian, gagasan inovatif maupun buku pelajaran.

Publikasi Ilmiah merupakan wadah untuk menyampaikan gagasan ilmiah hasil penelitian dan kajian akademik lainnya, dapat berupa artikel baik turunan dari skripsi, tesis, atau disertasi, maupun hasil telahaan yang diperentasikan dalam kegiatan seminar. Dalam publikasi ilmiah ini ada tiga jenis karya ilmiah yang dapat ditampilkan, yaitu berupa prosiding, jurnal, dan antologi (FBS UPI, 2010).

Publikasi ilmiah yang dilakukan guru pada dasarnya merupakan wujud dari profesionalisme guru. Steven R.Covey, (BPSDM-Kemendikbud, 2012) menyebutkan bahwa kegiatan publikasi ilmiah adalah salah satu bentuk upaya untuk memperbaharui mental.

Di Indonesia, kegiatan publikasi ilmiah di kalangan guru tampaknya mulai populer pada pertengahan tahun 90-an, seiring dengan dikukuhkannya guru sebagai jabatan fungsional (Kepmenpan No. 84/1993). Jika ditelaah lebih dalam, Isi Keputusan Menteri ini sebenarnya telah memberikan pesan tidak langsung kepada kita bahwa pada dasarnya guru adalah seorang ilmuwan. Hal ini sejalan dengan pemikiran Hamalik (2003) bahwa salah satu peran guru adalah sebagai ilmuwan, yang berkewajiban tidak hanya menyampaikan pengetahuan yang dimiliki kepada muridnya, akan tetapi juga berkewajiban mengembangkan pengetahuan itu dan terus menerus memupuk pengetahuan yang dimilikinya. Dengan kata lain, guru berkewajiban untuk membangun tradisi dan budaya ilmiah, salah satunya dalam bentuk Publikasi Ilmiah.

Kegiatan publikasi ilmiah guru semakin diperkuat dengan hadirnya Permenpan dan RB No. 16 tentang Jabatan Fungsional Guru dan Angka Kreditnya. Semula kewajiban publikasi ilmiah hanya dikenakan kepada guru yang akan naik pangkat dari Golongan IV.a ke atas. Namun berdasarkan Permenpan dan RB ini, kegiatan publikasi ilmiah guru harus dilakukan oleh guru yang akan naik ke golongan IIIc dijabarkan pada pasal 6. 
Berikut ini kutipan pasal 6 tentang kewajiban guru sebagai berikut: Kewajiban Guru dalam melaksanakan tugas adalah: merencanakan pembelajaran/bimbingan, melaksanakan pembelajaran/ bimbingan yang bermutu, menilai dan mengevaluasi hasil pembelajaran/ bimbingan, serta melaksanakan pembelajaran/perbaikan dan pengayaan; meningkatkan dan mengembangkan kualifikasi akademik dan kompetensi secara berkelanjutan sejalan dengan perkembangan ilmu pengetahuan, teknologi, dan seni.

Namun pada kenyataanya selama ini guru - guru masih banyak yang belum melakukan penelitian sehingga hanya sedikit hasil dari penelitian tersebut yang dipublikasikan. Hal ini juga terjadi di SD Gugus lima di Kecamatan Karangploso yang sebelumnya telah dilakukan pengabdian penulisan karya ilmiah. Berdasarkan wawancara yang diberikan kepada guru - guru tersebut, banyak diantara mereka yang belum mengetahui cara penulisan artikel dan proses untuk mempublikasikan hasil penelitiannya sehingga seringkali mereka meminta bantuan orang lain atau menjadikan guru putus asa untuk melakukan publikasi ilmiah, selain itu ada beberapa guru yang menyatakan bahwa tidak ada waktu karena banyaknya pekerjaan yang dimiliki di Sekolah.

Secara singkat dapat dijabarkan berbagai permasalahan yang dihadapi guru di gugus lima kecamatan Karangploso antara lain : 1). kurangnya pemahaman guru dalam mempublikasikan suatu karya ilmiah, 2). Kurangnya pemahaman guru tentang tahapan dalam mempublikasikan karya ilmiah, 3). Kurangnya motivasi guru untuk mempublikasikan suatu karya ilmiah.

Berdasarkan permasalahan yang disebutkan sebelumnya, diperlukan suatu program yang dapat membantu guru dalam menguasai keterampilan dalam hal publikasi. Salah satunya melalui kegiatan pengabdian. Kegiatan pengabdian ini bermaksud untuk memberikan pelatihan tentang penulisan artikel ilmiah pada jurnal dan prosiding bagi mitra dalam hal ini adalah guru di SDN Kecamatan Karangploso Malang. Mitra yang kami ambil adalah guru dari gugus V di SDN Kecamatan Karangploso Malang. Gugus V ini terdiri dari SD Ampeldento 01 dan SDN Ampeldento 2.

Kegiatan pengabdian ini dilakukan tiga kali pertemuan yang terdiri dari pelatihan pembuatan artikel untuk jurnal, pelatihan pembuatan artikel dan power point untuk prosiding. Harapan dari kegiatan ini adalah mampu memotivasi guru untuk secara produktif mempublikasikan ilmu yang didapatkannya dan hasil penelitiannnya sehingga dapat bermanfat bagi orang lain, sebagai wahana saling bertukar pemikiran antara pihak yang berkaitan dalam dunia pendidikan yang pada akhirnya dapat meningkatkan kualitas pendidikan secara umum di Indonesia.

Tujuan program pengabdian masyarakat ini diharapkan mampu memberikan luaran sebagai berikut: 1 . Meningkatkan motivasi guru dalam pengembangan kualitas pembelajaran serta aktif dalam menjalankan tugas fungsinya 2). Meningkatkan pemahaman guru dalam menyusun suatu artikel ilmiah, 3). Menghasilkan artikel ilmiah , 4). Terciptanya poster dan powerpoint prosiding, 5). Menyebar luaskan informasi dan hasil penelitian yang dapat berguna bagi orang lain.

\section{Metode Penelitian}

Kegiatan ini berupa pelatihan yang dilakukan dalam tiga kegiatan. Mitra dari kegiatan ini berasal dari guru SDN Ampeldento 01 dan 02 namun jumlahnya tidak sama dengan kegiatan sebelumnya, karena mitra pada kegiatan ini adalah guru yang telah mengembangkan karya ilmiah sebelumnya, yaitu sebanyak 15 orang dan memiliki karya ilmiah yang dapat dikliniskan untuk menjadi suatu artikel ilmiah.

Adapun langkah langkah program pengabdian pelatihan penyusunan artikel jurnal dan prosiding ilmiah terdiri dari: 1) Kegiatan pertama terdiri dari : a) Penyajian materi tentang manfaat dan pentingnya publikasi karya ilmiah bagi guru SD, b) Penyajian materi terkait langkah - langkah dalam membuat suatu artikel, c) Bimbingan konsultasi untuk menyusun suatu artikel penelitian, d) Presentasi artikel ilmiah mitra. 2) Kegiatan kedua terdiri dari: a) Penyajian materi terkait langkah membuat artikel ilmiah untuk seminar dan prosiding nasional maupun internasional, b) Penyajian materi pembuatan power point dan poster prosiding seminar nasional. 3) Kegiatan ketiga terdiri dari: a) Penyajian materi terkait tips dan triks mempublikasikan pada jurnal ilmiah dan prosiding ilmiah b) Pendampingan.

Beberapa cara untuk mendorong mitra agar memberikan partisipasi aktif dalam melaksanakan program pengabdian ini antara lain: 1). Adanya sosialisasi terlebih dahulu sebelum dilaksanakan kegiatan pelatihan, 2). Adanya kegiatan pendampingan yang akan mempermudah mitra untuk bertanya jawab tentang kesulitan yang dihadapi mitra dalam mengembangkan suatu artikel ilmiah, 3). Mengikutsertakan mitra dalam kepanitiaan kegiatan dalam penyebaran informasi dan perancangan kegiatan sehingga mitra lebih memahami tujuan kegiatan ini serta semangat dalam mengikuti kegiatan, 4). Memberikan sertifikat bagi mitra, sehingga dengaan sertifikat tersebut dapat digunakan untuk kepentingan karir mitra 


\section{Hasil Dan Pembahasan}

Hasil kegiatan pengabdian yang telah dilakukan menunjukkan bahwa pelaksanaan pengabdian pada guru SD gugus V di Kecamatan Karangploso cukup antusias, proaktif dan adanya rasa ingin selalu belajar muncul selama mengikuti program pelatihan. Program pengabdian ini terdiri dari:

a. Persiapan dan sosialisasi

Kegiatan persiapan dan sosialisasi dilakukan dengan tujuan untuk menyampaikan dan menginformaasikan program lanjutan pada program sebelumnya. Kegiatan persiapan dan sosialisasi dilakukan dengan beberapa tahapan: 1) Koordinasi dengan kepala sekolah mitra yaitu guru SDN ampeldento 01 dan Ampeldento 02 Gugus V Kecamatan Karangploso, 2) Koordiansi dengan panitia pelaksanaan pelatihan sebelumnya, 3) Merancang dan mendiskusikan kegiatan pelatihan yang akan dilakukan (pembuatan undangan, perancangan acara, perlengkapan dan konsumsi), 4) Persiapan pengembangan materi pelatihan dan kelengkapannya, 5) Sosialisasi dengan guru yang telah menyusun karya ilmiah pada program pengabdian sebelumnya.

b. Pelatihan Penyusunan artikel pada junal ilmiah

Kegiatan kedua pada program pengabdian ini adalah pelatihan pembuatan artikel pada jurnal ilmiah. Penyusunan artikel pada jurnal ilmiah terdiri dari beberapa kegiatan yang dilaksanakan oleh mitra dan tim pengabdi, diantaranya: 1) Pemaparan tentang publikasi dan pentingnya publikasi dalam dunia pendidikan, 2) Pemaparan konsep artikel ilmiah dan karya ilmiah, 3) Penjabaran bagian - bagian dan cara menyusn suatu artikel ilmiah, 4) Mitra dikenalkan dengan templet suatu jurnal, 5) Praktik secara bersama - sama penyusunan artikel ilmiah, 6) tanya jawab terkait penyusunan artikel dalam jurnal ilmiah.

Kegiatan ini berlangsung selama 5 jam dan diikuti secara penuh oleh guru yang hadir. Kendala pada kegiatan ini adalah beberapa guru masih banyak yang belum mempersiapkan karya tulis ilmiahnya dan juga ada beberapa guru yang kesulitan dalam menggunakan laptop atau komputer.

c. Pelatihan pembuatan artikel pada prosiding / seminar

Pelatihan pembuatan artikel pada prosiding atau seminar bertujuan untuk mengembangkan kemampuan guru dalam mengikuti seminar yang sering diadakan. Kegiatan pelatihan ini masih sama yaitu diikuti oleh 15 orang guru yang hadir pada kegiatan sebelumnya selama 5 jam. Kegiatan ini terdiri dari: 1) Pemaparan materi tentang prosiding dan jurnal ilmiah, 2) Pemaparan penyusunan artikel tentang prosiding, 3) Pemaparan penyusunan power point untuk kegiatan prosiding, 4) Tips dan trik dalam mengikuti seminar dan memilih jurnal ilmiah, 5) Penyusunan artikel prosiding dan power point seminar nasional maupun internasional, 6) Tanya jawab dan konsultasi penyusunan artikel dan powerpoin prosiding.

Kegiatan kedua mendapatkan apersiasi lebih baik dan berjalan lebih lancar daripada kegiatan sebelumnya , karena mitra teleah mengerti cara pembuatan artikel pada jurnal nasional, sehingga pada kegiatan kedua, mitra hanya sedikit membedakan cara penyusunan artikel pada jurnal dan juga prosiding. d. Pendampingan

Kegiatan pendampingan, dilakukan dengan cara secara nonformal artinya dilakukan ketika guru mengalami kesulitan dalam penyusunan artikel dan memperbaiki kualitas artikel yang telah disusun oleh mitra. Kegiatan pendampingan dilakukan dua kali yakni pendampingan dalam penyusunan artikel jurnal ilmiah dan pendampingan dalam penyusunan artikel prosiding ilmiah.

Hasil dari kegaiatan pendampingan: 1) Mitra masih belum 100\% mampu untuk menyesuiakan dengan templet yang diminta oleh suatu jurnal, 2) Mitra kesulitan mengerjakan pendahuluan dimana mengkaitkan antara latar belakang dengan teori yang digunakan, 3) Mitra kesulitan mengakses jurnal internasional

Adapun rencana tahapan selanjutnya adalah diharapkan adanya pendampingan dalam hal memasukkan dalam jurnal maupun seminar nasional ataupun internasional. Pendampingan dilakukan untuk membantu mitra sehingga mampu dan percaya diri untuk mengikuti kegiatan publikasi yang nantinya dapat bermanfaat bagi individu mitra maupun peningkatan kualitas pembelajaran di Indonesia pada umunya.

\section{Simpulan dan Saran}

Beberapa kesimpulan yang diperoleh dari kegiatan ini antara lain: 1) Kegiatan pengabdian kepada masyarakat pada program pelatihan pembuatan artikel ilmiah terdiri dari kegiatan persiapan dan sosialisasi, pelatihan penyusunan artikel pada jurnal ilmiah, pelatihan penyusunan artikel pada prosiding 
ilmiah serta pendampingan, 2) Mitra telah mampu menyusun artikel ilmiah untuk jurnal dan prosiding ilmiah, 3) Kegiatan pelatihan membantu mitra untuk melakukan publikasi, 4) Kegiatan pelatihan meningkatkan pertukaran antara pelaku pendidikan.

\section{Daftar Pustaka}

Hamalik, Oemar. 2003. Proses Belajar Mengajar. PT. Bumi Aksara, Jakarta.

FBS UPI. 2010. Publikasi Ilmiah. http://fpbs.upi.edu/publikasi-ilmiah/

Keputusan Menteri Negara Pendayagunaan Aparatur Negara Nomor 84 Tahun 1993 Tentang Jabatan Fungsional Guru Dan Angka Kreditnya.

Peraturan Menteri Negara Pendayagunaan Aparatur Negara Dan Reformasi Birokrasi Nomor : 16 Tahun 2009 Tentang Jabatan Fungsional Guru Dan Angka Kreditnya.

Peraturan Menteri Pendidikan Nasional, Nomor 35 Tahun 2010. Tentang Petunjuk Teknis Pelaksanaan Jabatan Fungsional Guru dan angka kreditnya. Kementrian Pendidikan Indonesia. 